\title{
THE INFLUENCE OF BIOLOGICALLY ACTIVE SUPPLEMENT "BIORIL"ON PERFORMANCE OF FATTENING LAMBS
}

\author{
Z. Ilić ${ }^{1}$, J. Stojković ${ }^{1}$, D. Ružić Muslić ${ }^{2}$, V. Caro Petrović ${ }^{2}$, \\ M. P. Petrović , R. D. Djoković ${ }^{3}$, V. S. Kurčubić ${ }^{3}$, \\ ${ }^{1}$ University of Pristina, Faculty of Agriculture, Kopaonicka bb, 38219 Lesak, Serbia \\ ${ }^{2}$ Institute for Animal Husbandry, P.O.Box. 23, 11081 Zemun, Belgrade, Serbia. \\ ${ }^{3}$ Faculty of Agronomy, Cara Dusana 34, 32000 Cacak, Serbia, University of Kragujevac \\ Corresponding author: ilzoama@open.telekom.rs \\ Original scientific paper
}

\begin{abstract}
Investigations were carried out in order to determine whether the addition of bioactive substances "Bioril" on different percentages in concentrate $(0.3 \%$ and $0.6 \%)$, has an impact on weight gain and feed conversion in lambs. For the experiment were used lambs of Mis sheep breed, which at the beginning of the experiment were 50 days of age. The experiment lasted 42 days, so it is over when all lambs had 92 days of age. The experiment included 60 lambs (30 male and 30 female) were divided into three groups-20 lambs per group (control group I and II and III experimental groups ). The results shows that the greatest gains made lambs of group III. The difference between body weight of group I and II was $1.62 \mathrm{~kg}$ and was statistically significant $(\mathrm{P}<0.01)$. The difference between body weight of I and III group was $1.87 \mathrm{~kg}$ and was also statistically significant $(\mathrm{P}<0.01)$. The difference between the body weight of II and III groups was $0.25 \mathrm{~kg}$ and was not statistically significant $(\mathrm{P}>0.05)$. We find that lambs of all groups consumed per $\mathrm{kg}$ of gain more concentrated than hay. The difference in feed conversion between groups is not significant $(\mathrm{P}>0.05)$, but lambs of groups III and II consumed per unit of gain approximately $5 \mathrm{~g} / \mathrm{kg}$ and $10 \mathrm{~g} / \mathrm{kg}$ less concentrate than lambs of group I. Most hay consumed by lambs of group I. The difference in hay consumption between groups I and II is $20 \mathrm{~g} / \mathrm{kg}$. Lambs in group III consumed $30 \mathrm{~g} / \mathrm{kg}$ which was less hay than group I and less $10 \mathrm{~g} / \mathrm{kg}$ than lambs of group II. The most energy per kg of gain was consumed by lambs of group III, whereas lambs in II group consumed the least energy.
\end{abstract}

lambs

Key words: sheep, bioactive supplement, bioril, fattening characteristics, 


\section{Introduction}

In majority countries of Europe, lamb meat is the most important product of the sheep and growth of lambs has special interest for the farmers. Growth of lambs depends on a number of genetic and environmental factors (Morris et al., 2000, Petrović, 2000, Petrović et al., 2011, Hansen and Shrestha, 2002, Notter et al., 2005). It is known that feeding is the most important factor that influences the expression of genetic potential of lambs (Santos et al., 2002, Ruzic Muslic et al, 2009). In the European Mediterranean countries lambs are traditionally reared with their dams in indoor conditions until weaning and there after fattened with concentrate (Safiudo et aI., 1998). The feeding of lambs is an important concentration of the meal. Energy is the major dietary element that is responsible for the different utilization of nutrients and thereby the productivity and gain of an animal (Bellof and Pallauf, 2004, Pittroff et al., 2006, Hosseini et al., 2008, Khalid et al, 2011). Because of the small volume of digestive organs of lambs on one side and greater intensity of growth on the other, some unconventional feeds are used, such as fats of animal origin (Diaz et al., 2002; Samy,2006; Ružić-Muslić et al., 2007). In addition to traditional nutrients, there are also various bioactive supplements. Bioactive Supplements "Bioril" is concentrated salt sodium fatty acids, which comes from sheep wool fat sweat. The fat content in it reaches over $60 \%$, including up to $90 \%$ free fatty acids, $6 \%$ of free alcohol, $1 \%$ of hydrocarbons, $2 \%$ aliphatic alcohol and a minor content of methyl esters of fatty acids. "Bioril" was developed in All-Russian Scientific Research Institute of Sheep and Goat Breeding-Stavropol, of the Russian Agricultural Academy (Efremov et al., 1992). Bioril is highly effective and environmentally clean product promotes active development of the microflora in the rumen, increased enzymatic processes, increase the total number of VFA and total lipids, while the hydrogenation processes are enhanced, there is a rapid growth of body weight and wool growth in sheep (Ermolovna, 1998, Novopashina, 1999).

The objective of this paper was to investigate the effect of "Bioril" on fattening characteristics of lambs in conditions outside of Russia.

\section{Material and methods}

Investigations were carried out on an experimental farm of sheep at the Institute of Animal Husbandry, Belgrade-Zemun. For the experiment were used lambs of Mis sheep, which at the beginning of the experiment were 50 days of age. The experiment lasted 42 days, so it is over when all lambs had 92 days of age The experiment included 60 lambs (30 male and 30 female) were divided into three groups-20 lambs per group (I control group and II and III experimental groups). 
The composition of the concentrate and content of "Bioril" in concentrate are shown in Table 1.

Table 1. Structure of concentrate mix, \%

\begin{tabular}{|l|c|c|c|}
\hline F e e d s & \multicolumn{3}{|c|}{ G r o u p s } \\
\hline I II III & I & II & III \\
\hline Corn & 66.3 & 66.0 & 65.7 \\
\hline Sunflower meal & 30 & 30 & 30 \\
\hline Bioril & 0 & 0.3 & 0.6 \\
\hline Chalk & 2 & 2 & 2 \\
\hline Salt & 0.7 & 0.7 & 0.7 \\
\hline Premix & 1 & 1 & 100 \\
\hline Total & 100 & 100 & 1 \\
\hline
\end{tabular}

In addition to the concentrate, lambs were fed alfalfa hay ad libitum. Water also was available ad libitum. Samples were analyzed using the conventional chemical process - WEENDE. Feed refusals were collected and weighed daily. Lambs were weighed before feeding initially and then at 7 day interval throughout the experimental period. After completion of 92-days experimental period, final live weight of each animal was recorded. Statistical analyses were performed with StatSoft STATISTICA Version 8.

Table 2. Nutritive value of feeds used in trial

\begin{tabular}{|l|c|c|c|}
\hline Feeds & FU & NEM/NME, MJ & $\begin{array}{c}\text { Undegradable } \\
\text { protein, } \%\end{array}$ \\
\hline Concentrate I & 1.23 & 7.28 & 0.38 \\
\hline Concentrate II & 1.30 & 7.39 & 0.38 \\
\hline Concentrate III & 1.34 & 7.48 & 0.39 \\
\hline Hay & 0.69 & 4.12 & 0.31 \\
\hline Milk & 0.39 & 2.34 & 0.71 \\
\hline
\end{tabular}

\section{Results and discussion} Table 3.

Body development of fattening lambs during the experiment is given in

It can be seen that the lambs at the start of experiments had the same age and body weight uniformity, which is varied in the range from 18:38 to $18: 40 \mathrm{~kg}$. This is the stage where lambs are adapted for consuming hay and concentrate and may give an answer on the composition and quality of nutrients. If we look at the results of the body weight of lambs at the end of the experiment, we can see that 
the lowest weight were in lambs of group I, while the lambs of group II and III had a higher final body weight.

Table 3. Performance of fattening lambs

\begin{tabular}{|l|c|c|c|}
\hline C r i t e r i o $\mathrm{n}$ & \multicolumn{3}{|c|}{ Groups } \\
\hline & I & II & III \\
\hline Initial body weight, $\mathrm{kg}$ & 18.39 & 18.40 & 18.38 \\
\hline Initial age, $\mathrm{d}$ & 50 & 50 & 50 \\
\hline Final body weight, $\mathrm{kg}$ & 31.75 & 33.37 & 33.62 \\
\hline Total gain, $\mathrm{kg}$ & 13.36 & 14.97 & 15.24 \\
\hline Average daily gain, $\mathrm{g}$ & 318 & 356 & 362 \\
\hline
\end{tabular}

The difference between body weight of the I and II group was $1.62 \mathrm{~kg}$ and was statistically significant $(\mathrm{P}<0.01)$. The difference between body weight of the I and III group was $1.87 \mathrm{~kg}$ and was also statistically significant $(\mathrm{P}<0.01)$. The difference between the weight of the body II and III groups was $0.25 \mathrm{~kg}$ and was not statistically significant $(\mathrm{P}>0.05)$.

The differences of total weight gain between control and experimental groups of lambs also has the same trend. The highest total weight gain were recorded in group III $(15.24 \mathrm{~kg})$ and lowest were in lambs of group I $(13.36 \mathrm{~kg})$. Daily gain in lambs of group III was higher for $12.15 \%$ compared with group I and $1.65 \%$ as compared to group II. Lambs in group II have higher daily gain then lambs of I group for $10.67 \%$. The reasons for the greater gain of the experimental groups of lambs was a product "Bioril", which promotes active development of the microflora in the rumen, increased enzymatic processes, increase the total number of VFA and total lipids, while the hydrogenation processes are enhanced, there is a rapid growth of body weight. These results are in agreement with the data quoted by Efremov et al., (1992), Novopashina (1999). If we look at the differences in growing lambs of group II and III, we can conclude that higher doses of "Bioril" $(0.6 \%$ compared to $0.3 \%)$ in our study did not give greater effect on growth of lambs. Ermolovna (1998) stated that the use of "Bioril" in feeding young sheep of 10-15 g per head per day provides an increase in body weight gain of sheep for $11.0-21.8 \%$, compared with the control, with better digestibility of feed, feeding of broiler chickens in amount of $2.5 \%$ by weight of feed - by $13.6 \%$ compared with the control. Our studies are consistent with Ruzic Muslic et al., 2009, Montossi et al., 2007, but there are authors who have different results. Titi et al. (2008) reported that yeast supplementation had no effect on growth rate in lambs and kids. Baranowski et al. (2007) also observed no difference in the mean daily live weight gain (238 g versus $225 \mathrm{~g}$ ) in lambs fed diet supplemented with linseed and mineral bioplex than lambs fed control diet only. This attests to the fact that the content of the food supplement has a major role. 
Table 4. Feed and nutrients conversion per $\mathrm{kg}$ of gain, $\mathrm{g} / \mathrm{kg}$

\begin{tabular}{|l|c|c|c|}
\hline Feeds & \multicolumn{3}{|c|}{ Groups } \\
\hline & I & II & III \\
\hline Milk & 740 & 670 & 730 \\
\hline Concentrate mixture & 1830 & 1820 & 1825 \\
\hline Alfalfa hay & 1350 & 1330 & 1320 \\
\hline DM & 2770 & 2751 & 2748 \\
\hline CP & 472 & 469 & 468 \\
\hline NEM,MJ/kg & 20.61 & 20.47 & 20.78 \\
\hline
\end{tabular}

In lambs production is very important that lambs consumed less feed per unit of gain. Only when we compare the gain with feed conversion, we can get a true picture of the genotype of lambs and the quality of the food consumed. From Table 4 we saw that lambs of all groups consumed per $\mathrm{kg}$ gain more concentrated than hay. The difference in feed conversion between groups is not significant $(\mathrm{P}>0.05)$. But lambs of groups III and II consumed per unit of gain approximately $5 \mathrm{~g} / \mathrm{kg}$ and $10 \mathrm{~g} / \mathrm{kg}$ less concentrate than lambs of group I. It is clear that lambs in II and III groups, which were fed with concentrate containing the "Bioril" consumed less concentrate per $\mathrm{kg}$ of gain. It is seen that the difference between experimental groups is small, only $5 \mathrm{~g} / \mathrm{kg}$. Ermolovna (1998) stated that inclusion in the diet of sheep "Bioril" contributes to the development of microorganisms in the rumen: the number of bacteria increased by $36.9 \%, 62 \%$ of the simplest. Change the microflora in the rumen contributes to the intensification of enzymatic processes, leading to an increase in total VFA in the rumen contents of $12 \%$, mainly due to acetic and valeric acids. Number of total lipids in the rumen contents increased by $34 \%$ hydrogenation processes are enhanced essential fatty acids. It could be concluded that the higher content of bioactive supplement "Bioril" by microbiological and biochemical effects in the process of digestion, improved some sensory properties of the concentrate, which makes it more lambs consumed. Can say that Bioril has a similar effect of probiotics because, as stated Dutta et al.(2009) positive effects of probiotics on the rumen environment and performance of ruminants have been intensively studied because they can beneficially modify microbial activities, fermentative and digestive functions in the rumen. It is further stated that probiotics can stimulate specific groups of beneficial bacteria in the rumen, and has provided mechanistic models that can explain their effects on animal performance. From the table 4, we can see that most hay consumed by lambs of group I. The difference between groups I and II is $20 \mathrm{~g} / \mathrm{kg}$. Lambs in group III consumed $30 \mathrm{~g} / \mathrm{kg}$ less than group I and less $10 \mathrm{~g} / \mathrm{kg}$ than lambs of group II. The most energy per $\mathrm{kg}$ of gain consumed lambs of group III, whereas lambs in II group consumed the least energy. Other authors also reported that the energy level in the diet affects the growth of lambs. Seyed (2009) informed that the feed intake was higher for group fed on low energy diet compared with other treatment groups. The weight gain of the lambs fed on high-energy diet was increased by 
$31.60 \%$, while those fed on low energy diet was decreased by $19.87 \%$. The feed conversion was better in the group fed on high energy compared to other experimental groups. Ruzic et al.(2009) reported that With increase of diet concentration by adding $4 \%$ of tallow in forage mixture,tendency of reduction of consumption of dry matter, energy and protein per $\mathrm{kg}$ of gain was observed. Bahtiyarca et al. (2002) showed that the increase in protein and energy content of diets decreased the voluntary food intake.

\section{Conclusion}

Based on research conducted and the obtained results, we can conclude the following: the experimental groups of lambs that were fed concentrates with "Bioril" achieved higher daily gain, compared with the control group $(\mathrm{P}<0.01)$. The difference between body weight of the groups II and III was not statistically significant $(\mathrm{P}>0.05)$. The difference in feed conversion between groups is also not significant $(\mathrm{P}>0.05)$. Therefore, it is clear that experimental groups of lambs, which were fed with the concentrate containing the "Bioril" consumed less concentrate per kg of gain. We can also conclude that most hay consumed by lambs in group I. The most energy per $\mathrm{kg}$ of gain was consumed by lambs of group III, whereas lambs in group II consumed the least energy.

\section{Acknowledgements}

This study is part of the projects TR 31001 "An environmental approach and implementation of modern biotechnologies as a basis for the improvement of ruminant breeding technology", and TR 31053 "Modern biotechnology solutions in the breeding and feeding of cattle sheep and goats for the production of valuable and safety food" financially supported by the Ministry of Education, Scienceand Technological development of the Republic of Serbia.

\section{Uticaj bioaktivnog dodatka Biorila na rezultate jagnjadi u tovu}

Z. Ilić, J. Stojković, D. Ružić Muslić, V. Caro Petrović, M. P. Petrović, R. Djoković, V. S. Kurčubić

\section{Rezime}

Istraživanja su sprovedena kako bi se utvrdilo da li dodavanje bioaktivne supstance "Bioril" u različitim procentima u koncentratu $(0,3 \%$ i $0,6 \%)$, ima uticaj na prirast i konverziju hrane u jagnjadi. Za eksperiment su korišćena jagnjad od ovaca rase Mis, koja su na početku eksperimenta bila 50 dana starosti. Eksperiment 
je trajao 42 dana, tako da je završen kada su jagnjad imala 92 dana starosti. U eksperiment je uključeno 60 jagnjadi (30 muškog i 30 ženskog pola). Jagnjad su podeljena $\mathrm{u}$ tri grupe-20 jagnjadi po grupi (kontrolna grupa I i II i III eksperimentalne grupe). Rezultati pokazuju da su ostvareni najveći dnevni prirasti kod jagnjadi II eksperimentalne grupe. Razlika između telesne mase grupe I i II je $1.62 \mathrm{~kg}$ i bila je statistički značajna $(\mathrm{P}<0,01)$. Razlika između telesne mase I i III grupe je bila $1,87 \mathrm{~kg}$ i takođe je bila statistički značajna $(\mathrm{P}<0,01)$. Razlika između telesne mase II i III grupe je bila $0,25 \mathrm{~kg}$ i nije bila statistički značajna $(\mathrm{P}>0,05)$. Smatramo da je jagnjad svih grupa konzumirala po kg prirasta više koncentrata nego sena. Razlika u konverziji hrane između grupa nije značajna $(\mathrm{P}>0,05)$, ali jagnjad grupe III i II troši po jedinici prirasta oko $5 \mathrm{~g} / \mathrm{kg}$ i $10 \mathrm{~g} / \mathrm{kg}$ manje koncentrata nego jagnjad grupe I. Više sena troše jagnjad iz I grupe. Razlika u potrošnji sena između grupa I i II je $20 \mathrm{~g} / \mathrm{kg}$. Najviše energije po $\mathrm{kg}$ prirasta troši jagnjad iz III grupe, dok jagnjad iz II grupe troši najmanje energije.

\section{References}

BAHTIYARCA Y., AKTAS A.H., CUFADAR Y. (2002): The effect of diets with different levels of energy on fattening performance and carcass characteristics of Konya merino lambs and muttons. Selcuk Univ. Zir. Fak. Derg., 16: 19-25.

BARANOWSKI A., GABRYSZUK M., JOZWIK A., BERNATOWICZ E., CHYLINSKI W. (2007): Fattening performance, slaughter indicators and meat chemical composition in lambs fed the diet supplemented with linseed and mineral bioplex. Anim. Sci. Papers Rep., 25: 35-44.

BELLOF G., PALLAUF J. (2004): Deposition of protein, fat and energy in lambs of the breed German Merino Land sheep. Anim. Sci., 78(3): 369-378.

D. RUŽIĆ-MUSLIĆ, M. P. PETROVIĆ, Z. BIJELIĆ (2009): The effect of beef tallow in lamb nutrition on fattening and carcass characteristics. Biotechnology in Animal Husbandry 25:431-438.

DIAZ M.T., VELASCO S., CANEQUE V., LAUZURICA S., RUIZ DE HUIDOBRO F., PEREZ C., GONZALES J., MANZANARES C. (2002): Use of concentrate or pasture for fattening lambs and its effect on carcass and meat quality. Small Ruminant Res., 43, 257268.

DUTTA T. K., KUNDU S. S., KUMAR M. (2009): Potential of direct-fedmicrobials on lactation performance in ruminants - A critical review. Livest. Res.Rural Dev., 10: 219-227.

ERMOLOVNA L. S. (1998): Biologically active substances from the animal side of raw materials - study the mechanisms of formation and action, the production of forms used in animal husbandry and medicine. Doctoral dissertation. Russian academy of agricultural sciences, VNIIOK, Stavropol.

HANSEN C., SHRESTHA J. N. B. (2002): Consistency of genetic parameters of productivity for ewes lambing in February, June, and October under an 8-month breeding management. Small Rum. Res., 44, 1-8. 
HOSSEINI S. M. (2008): Effect of different energy levels of diet on feed efficiency, growth rate and carcass characteristics of fattening lambs. J. of Anim. \& Vet Adv., 7(12): 1551-1554.

KHALID M. F. L., SHAHZAD M. A., SARWAR M., REHMAN, A. U., SHARIF M., MUKHTAR N. (2011): Probiotics and lamb performance. African Journal of Agricultural Research Vol. 6:5198-5203.

MONTOSSI F., LUZARDO S., DE BARBIERI I., SAN JULIÁN R., FRANCO R., GUTIÉRREZ D., BRITO G. (2007): Effect of stocking rate and suplementation on lambs grazing Lotus corniculatus cv. Inia Draco during summer in Uruguay. In: Proceedings 53rd ICoMST . Ed. Zhou, G. and Zhang, W. China Agricultural University, Beijing, China. pp 283-284.

MORRIS C. A., HICKEY S. M., CLARKE J. N. (2000): Genetic and environmental factors affecting lamb survival at birth and through to weaning. NZ. J. Agric. Res., 43, 515-524.

NOTTER D. R., BORG R. C., KUHEN L. A. (2005): Adjustment of lamb birth and weaning weights for continuous effects of ewe age. Anim. Sci., 80, 241-249.

NOVOPASHINA S. I. (1999): Growth of fine-wool lambs at different stages of ewes lambing and feeding their BAS purivetin. Doctoral dissertation. Russian academy of agricultural sciences, VNIIOK, Stavropol.

PETROVIC P. M. (2000): Genetic and improvement of sheep. Sci. Book, Belgrade, pp. 365.

PETROVIC P. M., RUZIC MUSLIC D., CARO PETROVIC V., MAKSIMOVIC N. (2011): Influence of environmental factors on birth weight variability of indigenous Serbian breeds of sheep. African Journal of Biotechnology. 10: 46734676.

PITTROFF W, D. H. KEISLER, H. D. BLACKBURN (2006): Effects of a highprotein, low-energy diet in finishing lambs:1. Feed intake, estimated nutrient uptake, and levels of productivity for ewes lambing in February, June, and October under an 8-month quality. Small Ruminant Res., 43, 257268.

PITTROFF, W., KEISLER, D. H., BLACKBURN, H. D. (2006): Effects of a high protein - low energy diet in finishing lambs 1 Feed intake estimated nutrient uptake and levels of plasma metabolites and metabolic hormones. Livest. Prod. Sci. 101, 262-277.

RUŽIĆ D., GRUBIĆ G., PETROVIĆ P.M., NEGOVANOVIĆ D., NEŠIĆ Z., PERISIC P., ZUJOVIC M. (2007): The effect of the level of non degradable protein on digestibility of nutritive substances in fattening lambs. Biotechnology in Animal Husbandry, 23, 5-6, 131-137.

SANTOS-SILVA J., MENDES I. A., BESSA R. J. B. (2002): The effect of genotype, feeding system and slaughter weight on the quality of light lambs. 1 . Growth, carcass composition and meat quality. Livest. Prod. Sci., 76, 17-25. STATISTICA (data analysis software system), version 8. www.statsoft.com. 